\title{
Assessment on the authenticity of imported honey in Ethiopia
}

\begin{abstract}
Ethiopia is known for its tremendous variation of agro-climatic conditions and biodiversity which favored the existence of diversified honeybee flora and huge number of honeybee colonies. The word "import" is derived from the word "port," since goods are often shipped via boat to foreign countries. Along with exports, imports form the backbone of international trade; the higher the value of imports entering a country, compared to the value of exports, the more negative that country's trade balance. When we see the trends of import and export of honey the amount of exported honey to the global market is greater than the amount of honey imported to the country. In terms of price the average price imported and exported honey is 1.8 and 2.7USD respectively. This study has needed to investigate the legality or authenticity of the imported and locally produced honey and other beehive products. For the study three towns (Addis Ababa, Adama and Bishoftu) were selected with purposive sampling method. A total of 28 supermarkets and 12 international hotels from Addis Ababa, Adama and Bishoftu were selected randomly and 5 concerning government organizations were interviewed. The collected data's were analyzed using simple descriptive statistics method and some figures were interpreted using graphs. It is identified that large amount honey products is imported from different countries, and used by the consumers at international hotels and supermarkets. A as per the data from ministry of trade total of ten legally registered and functionally active natural honey importers are found in the country. All the concerned respondent replay that their service typically include local origin honey namely, Tutu honey, Tadel natural honey, Ethio honey and etc and the packaging material is plastic. Except one supermarket And one international hotel (SHERTONE ADDIS AND SAFEWAY SUPERMARKET) their service include imported honey and locally produced honey with glass bottle and plastic respectively. The quality of locally produced honey and other bee-hive product quality tasted and controlled by ECA and EFMHACA. Finally the study conclude that there are honey importers in the country but the quality and safety of the imported honey is not inspected by the concerned bodies so the study recommended that Stakeholders on quality and safety institution should work together to inspect and to give the competence certificate for the imported and locally produced honey (EFMHACA, ECA \& MT), Introducing market legal framework for the sector and Creating conducive environment as the packaging materials can made in the country could improve the sector performance.
\end{abstract}

Keywords: import, quality, honey
Volume 8 Issue 6 - 2018

\section{Hana Tadesse Kebede, Tigest lemma, Gezahege Dugassa}

Ethiopian Meat and Dairy Industry Development Institute (EMDIDI), Ethiopia

Correspondence: Hana Tadesse Kebede, Bsc in Animal science, Ethiopian Meat and Dairy Industry Development Institute (EMDIDI), Ethiopia, Email hanesha2@yahoo.com

Received: July 18, 2018 | Published: November 23, 2018
Abbreviations: EFMCA, Ethiopian food and medicine control authority; ECA, Ethiopian conformity agency; MT, ministry of trade; EMDIDI, Ethiopian meat and dairy industry development institute.

\section{Introduction}

Ethiopia is known for its tremendous variation of agro-climatic conditions and biodiversity which favored the existence of diversified honeybee flora and huge number of honeybee colonies. ${ }^{1}$ It has the largest bee population in Africa with over 10million bee colonies, out of which about 5 to 7.5 million are estimated to be hived while the remaining exist in the wild (MoARD 2007; CSA 2009). This makes Ethiopia a leading in Africa and ninth in the world in honey production. Similarly, it stands first in Africa and third in the world in beeswax production (FAOSTAT data 2005). Ethiopia has a longstanding beekeeping practices that has been an integral part of other agricultural activities, where more than one million households keep honeybees. ${ }^{2}$ Beekeeping subsector is dominantly for small-scale farmers and is contributing significantly to the increment off-farm income and toward poverty reduction in rural areas (MoARD 2007). Honey is considered as cash crop and only about $10 \%$ of the honey produced in the country is consumed by the beekeeping households (MoARD 2003). The remaining $90 \%$ is sold for income generation. ${ }^{3}$ Beeswax was also in the list of Ethiopian agricultural export commodities, though it was only in 2008 that the country got the EU accreditation to export its honey to EU market. ${ }^{4}$ The beekeeping subsector is also creating job opportunities in both rural and urban areas. ${ }^{4}$ Recently, the Ethiopian government is intensively working in organizing jobless urban and landless rural youth and women to involve in them in bee equipment production and beekeeping activities. A significant number of people are currently engaged in honey and beeswax collection, "tej" (honey wine) making, honey and beeswax processing and marketing (MoARD 2007). The word "import" is derived from the word "port," since goods are often shipped via boat to foreign countries. Along with exports, imports form the backbone of international trade; the higher the value of imports entering a country, compared to the value of exports, the more negative that country's balance of trade becomes. 
Countries are most likely to import goods that domestic industries cannot produce as efficiently or cheaply but may also import raw materials or commodities that are not available within its borders. For example, many countries have to import oil because they cannot produce it domestically or cannot produce enough of it to meet demand. Free trade agreements and tariff schedules often dictate what goods and materials are less expensive to import. ${ }^{5-7}$

When we see the trends of import and export of honey the amount of exported honey to the global market is greater than the amount of honey imported to the country .In terms of price the average price imported and exported honey is 1.8 and 2.7USD respectively. The main buyers of Ethiopian honey are Germany, United Kingdom, Sudan, Norway, Saudi Arabia, and Yemen. The main buyers of beeswax are Germany, Japan, United States, United Kingdom and Italy. Despite of the big market for honey and beeswax, producers are less exposed to quality standards suitable for domestic or external market hence resulting in fetching low price Honey and bees- wax product processing industry development directorate has been working with multi-stakeholders including government and private sectors in identifying the barriers on production, processing and marketing of honey and other bee-hive product. As a result, a number of intervention activities have been carried out to face the challenges thereby develop the subsector, especially honey and other bee products. This study has needed to investigate the legality or authenticity of the imported and locally produced honey and honey bee products, and marketing opportunities and challenges in general.

\section{Objectives}

The main objective of this study was to assess the legality or authenticity of the imported and locally produced honey and honey bee products.

i. To identify the problems related to imported honey and recommend the possible solutions to respective bodies,

ii. To identify the potential importers of natural honey and other bee-hive product

iii. To collect data which can be used as input for future studies

\section{Methodology}

\section{Sampling methods}

In this study a purposive sampling method was used to select the 3 towns. A total of 28 supermarkets and 12 international hotels from Addis Ababa, Adama and Bishoftu were selected randomly and 5 concerning government organizations were interviewed. A formal pre tested structured and semi structured questionnaires were used to collect the data's concerning the amount of imported natural honey, its economic influence, quality and safety control of imported honey and the packaging equipments. The secondary data's like the amount of honey imported during the last five years, the pre requisites to have an imported permission license, quality and safety standards inspection and regulatory mandates of concerned organizations were collected from governmental offices.

\section{Data analyses}

The collected data's were analyzed using simple descriptive statistics method and some figures were interpreted using graphs.

\section{Results and discussions}

Ethiopian Meat and Dairy Industry Development Institute (EMDIDI) is embarking on developing globally competitive industry in livestock processing sub- sector through providing necessary capacity building, investment facilitations, conducting problem oriented researches and market development support. The country's livestock resources potential and the positive trends observed in augmenting foreign exchange earnings and employment generation from the sub sector has drawn the attention of the government and the private sector. In the second GTP, the contribution of the sub sector towards developing agro-processing industries, increasing foreign exchange earnings and improving employment generation has been well recognized. Accordingly, ambitious but attainable targets have been set. However, to meet the targets, it entails addressing the multifaceted challenges constraining the subsector's development. Most of directly and indirectly respective Government and non government bodies have been addressed in this assessment. Those are Ethiopian conformity assessment enterprise, Ethiopian Food, Medicine and Health Control Authority, Ministry of Trade, Ethiopian Revenue and customs authority, International Hotels, Ethiopian Honey and bees wax processors and exporters association and Supermarkets.

As the information obtained from ministry of trade indicate that there are honey products imported from different countries, and consumed by international hotels and some supermarkets a total of ten legally registered and fictionally active natural honey importer in the country, namely (Table 1). As the table shows most of the importers located in the capital city of Ethiopia and only one importer company found in Bishoftu town. About $77.78 \%$ of the owners have Ethiopian citizen and the rest $22.2 \%$ are foreigners. The perquisite for to have importing goods from abroad include taxpayer identification number, document evidencing the capital allocated, for S.C, certificate of professional competence, valid identification card or passport and obtaining business license for sole proprietor via proxy is prohibited. All the importer had fulfilled the above requirement. For as the conformity assessment and Ethiopian Medicine quality control/ EFMCA/as the interviewed they have the legal obligation to control the quality of the imported goods but regarding the import of natural honey they did not give proficiently competence certificate to natural honey importers and did not evaluate the quality of natural honey imported to the country as the Ethiopian Conformity Assessment Agency they are evaluating the quality of the product based on the customers demand and they did not test the quality of imported honey so far. The major actors regarding the quality and safety control for food and human medicine are EFMCA and ECA.

Table I Potential importer of natural Honey and origin countries

\begin{tabular}{|c|c|c|c|c|}
\hline $\begin{array}{l}\text { S. } \\
\text { no }\end{array}$ & Name of company & Nationality & $\begin{array}{l}\text { Address/ } \\
\text { place }\end{array}$ & $\begin{array}{l}\text { Phone } \\
\text { number }\end{array}$ \\
\hline I & ALFRAG PLC & Ethiopian & A.A & 112753633 \\
\hline 2 & Novise PLC & Italian & Bishoftu & 116614722 \\
\hline 3 & $\begin{array}{l}\text { Dja agonafer and his } \\
\text { children PLC }\end{array}$ & Ethiopian & A.A & $1 \mid 4656116$ \\
\hline 4 & Fantu family :3PLC & Ethiopian & A.A & $1137 \mid 2223$ \\
\hline 5 & Adalberto frza PLC & Italian & A.o & 111557049 \\
\hline 6 & $\begin{array}{l}\text { Pollydorcher } \\
\text { mokonnenPLC }\end{array}$ & Ethiopian & A.A & 943434343 \\
\hline
\end{tabular}


Table Continued

\begin{tabular}{cllll}
\hline $\begin{array}{l}\text { S. } \\
\text { no }\end{array}$ & Name of company & Nationality & $\begin{array}{l}\text { Address/ } \\
\text { place }\end{array}$ & $\begin{array}{l}\text { Phone } \\
\text { number }\end{array}$ \\
\hline 7 & $\begin{array}{l}\text { Ngemedine keder } \\
\text { hassen PLC }\end{array}$ & Ethiopian & A.A & \\
8 & $\begin{array}{l}\text { Tehluf investement } \\
\text { PLC }\end{array}$ & Ethiopian & A.A & 930077225 \\
9 & $\begin{array}{l}\text { Famihone terading } \\
\text { PLC }\end{array}$ & Ethiopian & A.A & 911228294 \\
\hline
\end{tabular}

The secondary data obtained from Ethiopian custom and revenue authority indicate that in the past 5years 23.67 tone of natural honey imported around the world. As the graph indicate the origin of natural honey imported from Egypt, France, United Kingdom, Italy, United Arab Emirates, USA, Germany, Denmark, Australia, and Iran, China and Korea. The origin of natural honey imported to the country based on the amount France is the leading country followed by Egypt and England. But most of the imported honey re imported from United Arab Emirates, because most of the honey brad that means Tip tree and ORGANA are not allowed to ship directly to Ethiopia. When we compare the amount of imported and exported natural honey from 2004-2008 E.c as Graph 1 shows the amount of natural honey exported to the global market is greater than the amount of honey imported to the country. In terms of price the average price imported and exported honey is 1.8 and 2.7USD respectively Graph 2. For this assessment 28 supermarkets and 12 international hotels were observed and interviewed all the concerned respondent replay that their service typically include local origin honey namely, Tutu honey, Tadel natural honey, Ethio honey and etc and the packaging material is plastic. Except one supermarket and one international hotel (SHERTONE ADDIS AND SAFEWAY SUPERMARKET) their service include imported honey and locally produced honey with glass bottle and plastic respectively (Figure 1). The main reason they imported natural honey is that the local honey have no standard packaging equipment (glass), adulteration and quality the major ones. The imported honey brand is ORGANA and Tip tree shipped from UAE but the origin of the honey is England. They import honey when necessary and for concerning Sheraton Addis hotel the main customer are foreign people and they serve $33 \mathrm{gm}$ tip tree honey for room service but for events and large occasion they serve local honey with bowel. In the case of safe way supermarket the major customer are urban people when we interviewed the supermarket manager the reason that the urban people choosing imported honey over local honey because of adulteration and poor packaging material and lack of confidence in the quality of locally produced honey.
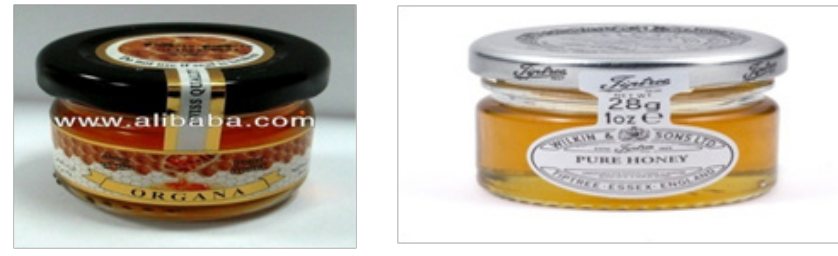

Figure I Imported honey.

When we assess the supermarket and International hotels the main supplier of local honey is tutu honey this company also among the leading exporter selling its product to foreign market for the past ten years. Now a day's these export company not working using its full potential The reason behind include absence of market legal frame work, Seasonal availability of honey, lack of standardized packaging materials manufacturing industry, absence of regular inspection, Adulteration problem and high price of local honey. But most of the respondent replied that Ethiopian honey have high demand in the international market if its quality, packaging material and regular inspection is improved.

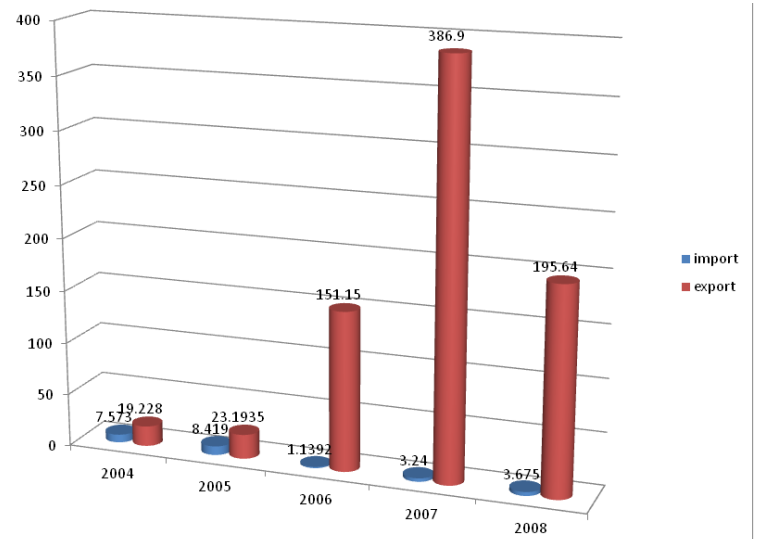

Graph I Shows the amount of natural honey exported to the global market is greater than the amount of honey imported to the country.

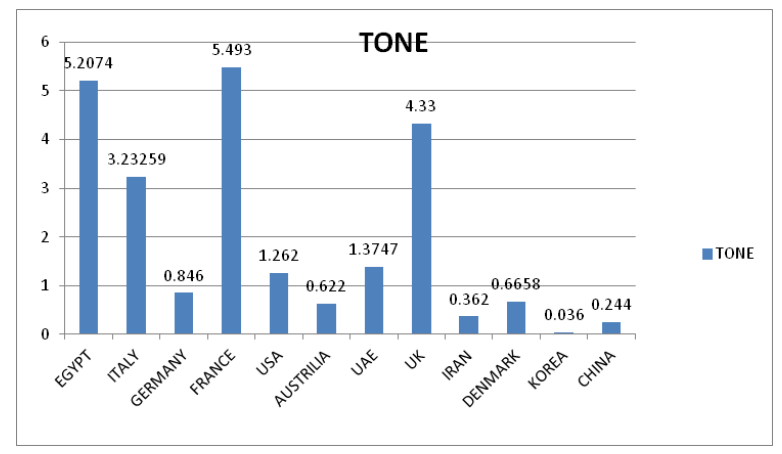

Graph 2 Origin of country Ethiopia imported Natural honey.

\section{Conclusion}

According to this assessment there are ten legally registered natural honey importers in Ethiopia. The main criteria legal importing goods include taxpayer identification number, document evidencing the capital allocated, for S.C, certificate of professional competence, valid identification card or passport and obtaining business license for sole proprietor via proxy is prohibited. All the importer had fulfilled the above requirements. For as the Ethiopian Food, Medicine and Health Care Administration and Control Authority (EFMHACA) as the interviewed they regulate the quality of imported and exported honey and other bee product they have the legal authority to give the proficient competence certificate for both the local and exported honey and other bee products. The major stakeholders to regarding the quality and safety control are ECA \& EFMHACA. As the information obtained from Ethiopian Custom and Revenue Authority in the past five years 23.76 tone natural honey imported from different country namely France, Egypt and England. The trend of honey export for the past five years shows that it is decreasing. When we compare the amount of natural honey imported and exported in the past five years the amount of honey exported is larger than the imported one. In terms of USD the average price for imported and exported is 1.8 and 2.7USD respectively. For these assessments 28 supermarkets and 12 international hotels were observed and interviewed all the concerned respondent replay that their service typically include local origin honey namely, Tutu honey, Tadel natural honey, Ethio honey and etc and the packaging material is plastic. Except one supermarket And one international hotel (SHERTONE ADDIS AND SAFE 
SUPERMARKET) their service include imported honey and locally produced honey with glass bottle and plastic respectively (Figure 1). The main reason they imported natural honey is that the local honey have no standard packaging equipment that means glass, adulteration

Table2 List of Offices/Ministry/agency/ International hotels, supermarket addressed in this study

\begin{tabular}{|c|c|c|c|c|c|}
\hline s.no & Name & Manager's name & Phone no & Address/place & Remark \\
\hline I & Ministry of Trade & & & A.A & \\
\hline 2 & $\begin{array}{l}\text { Ethiopian conformity assessment } \\
\text { enterprise }\end{array}$ & & 116670246 & A.A & \\
\hline 2 & EFMAACA & Mulugeta & 913471096 & & \\
\hline 3 & Ethiopian Revenue and customs authority & Getachow & 115157286 & A.A & \\
\hline 4 & Sheraton Addis hotel & & 115171717 & A.A & \\
\hline 5 & Hilton hotel & & 911201745 & A.A & \\
\hline 6 & Jupiter intern. hotel & Nahuu & 929216371 & A.A & \\
\hline 7 & Capital intern. hotel & & & A.A & \\
\hline 8 & Ililli intern. hotel & & & A.A & \\
\hline 9 & $\begin{array}{l}\text { Ethiopian Honey and bees wax } \\
\text { processors and Exporters Association }\end{array}$ & Eliyaas & 911606191 & A.A & \\
\hline 10 & Novis supermarket & & & A.A & \\
\hline II & Shisolomon supermarket & Solomon & 1116116567 & Meganagna & \\
\hline 12 & Safeway supermarket & & 930012593 & & \\
\hline 13 & Bambiis supermarket & & II5505584 & & \\
\hline 14 & Fresh corner supermarket & alemsegad & & & \\
\hline 15 & Ethiopian airlines & & 911255446 & BOLE & \\
\hline 16 & Harmony Hotel & & 933696420 & BOLE & \\
\hline
\end{tabular}

\section{Recommendations}

i. EMDIDI AND MOLF should work together to put in place and implement beehive products marketing and quality administration and regulation mechanism for the sector

ii. Creating awareness on the imported honey quality control for all stakeholders across the value chain

iii. Honey and other bee-hive products Sampling ,tasting and certification bodies in particularly to import and export should develop integrated service provision

iv. Encourage, support and facilitate the production and supply of packaging materials manufacturing industry in the country.

\section{Declaration}

Our manuscript does not report on or involve the use of any animal or human data or tissue, this section is not applicable to our submission.

\section{Acknowledgments}

We would like to acknowledge Ethiopian Meat and Dairy Industry Development Institute for their technical and material supports to carry out the study and yeshitela esahte for his guidance. Our appreciation extended to Ethiopian Conformity Assessment Enterprise, Ethiopian Food, Medicine and Health Control Authority, Ministry of Trade, Ethiopian Revenue and customs authority, International Hotels, Ethiopian Honey and bees wax processors and exporters association and Supermarkets for their valuable information regarding these study. and quality the major ones. The imported honey brand is ORGANA and Tip tree shipped from UAE but the origin of the honey is England (Table 2).

\section{Conflicts of interest}

The authors declare that there is no conflicts of interest.

\section{References}

1. Abebe A. Market chain analysis of honey production: in Atsbi Wemberta District, Eastern Zone of Tigray National Regional State. $A$ Thesis Submitted to College of Agriculture Department of Agricultural Economics, School of Graduate Studies. Haramaya University, Haramaya. 2009.

2. Adgaba N, Negera E. Unpublished: Study on means of retarding the unwanted granulation of table honey. Holeta Bee Research Center, progressive report, Holeta, Ethiopia. 2007.

3. Hartmann I. The management of resources and marginalization in beekeeping Societies of Southwest Ethiopia. Paper submitted to the conference: Bridge Scales and Epistemologies. 2004.

4. Assefa M. Pro-poor value chains to make market more inclusive for the rural poor: Lessons from the Ethiopian honey value chain. Danish Institute for International Studies, Copenhagen, Denmark. 2011; p. $35-50$.

5. Adgaba N. Unpublished: Study on means of maintaining finely and uniformly granulated table honey. Holeta Bee Research Center, progressive report, Holeta, Ethiopia. 2009.

6. Adgaba N. Atlas of pollen grains of major honeybee flora of Ethiopia. Holeta Bee Research Centre. Commercial Printing Enterprise. Addis Ababa, Ethiopia. 2007; p. 152.

7. Adgaba N, Negara E, Zuber S. Unpublished: Profitability of processing crude honey. Holeta Bee Research Center, progressive report, Holeta, Ethiopia. 2006. 